レーザーレター

$$
\begin{gathered}
\text { レーザーアブレーション粒子の速度選択成膜 } \\
\text { 杉原 忠*.久芳 完 治* }
\end{gathered}
$$

(1995年3月6日 受理)

\title{
Deposition by Velocity Selection of Laser Ablated Particles
}

\author{
Tadashi SUGIHARA * and Kanji KUBA*
}

(Received March 6, 1995)

\begin{abstract}
An apparatus with a rotating mechanical chopper for thin film production has been developed. It is demonstrated that the energy of ablated particles is well selected by this method. Further, this method is applicable to Au thin film deposition and is recognized to be useful to improve thin film quality because the number of droplets in the film are drastically decreased.
\end{abstract}

Key Words: Laser ablation, Thin film, Velocity, Particle

1.はじめに

レーザーアブレーションによる薄膜形成技術 は, 従来より各種薄膜の形成に利用されてきた。 特にエキシマレーザーによる薄膜作製は，高い 組成制御性や，作製された膜特性が優れている などの特徵を有しているため, 近年, 高温超伝 導薄膜などの機能性酸化物薄膜などにおいて, 盛んに研究されている。

薄膜形成時における付着粒子の持つ運動エネ ルギーは，作製される薄膜の膜密度や内部応力 など，膜の諸特性を決める上で重要な因子と考 えられている。エキシマレーザーアブレーショ ンでは, 原子・イオン・励起種等が形成され, 成 膜には幅広いエネルギーの粒子が利用される。 成膜に利用される粒子の持つ運動エネルギーを コントロールする事は，膜特性の制御に有効な
手法であると考えられる。またエキシマレー ザーによるアブレーションでは，パルス状に成 膜される粒子が発生する。今回この特徵を利用 し, 成膜粒子の持つ付着速度の範囲を変えるこ とが可能な装置を開発したので，本方式の原理 及び特性ついて報告する。

\section{2. 原理及び実験方法}

Fig.1に本実験で用いた装置の概念図を示す。 ターゲット上にスリットを持つ円盤(メカニカ ルチョッパー)を置き，このメカニカルチョッ パーを高速で回転させ，スリットにより飛行し てきた粒子をカットすることにより，アブレー ション粒子のエネルギーの選択を行うことを基 本原理としている。このときチョッパーの回転 とレーザーとを同期させる必要がある。同期の 方法としてはターゲットと $180^{\circ}$ 対向する位置に 


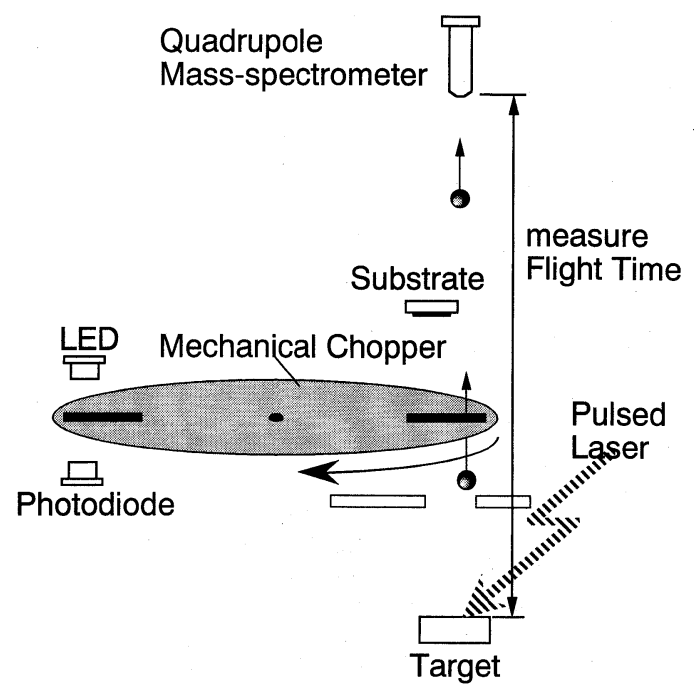

Fig. 1 Schematic diagram of the apparatus.

フォトカプラを置きスリットの位置検出を行っ た。ターゲットは2 10 rpmで回転可能であり, 上下方向に移動させることにより，チョッパー との距離を20〜80 mm(基板との距離で30９0 $\mathrm{mm})$ の範囲で可変とした。

レーザーアブレーションにより形成される粒 子は $5 \times 10^{6} \sim 2 \times 10^{4} \mathrm{~cm} / \mathrm{sec}^{1)}$ と幅広い運動速度 分布を持つことが報告されている。高速で飛来 してくる粒子をカットするためにメカニカル チョッパーは, 真空中で高速に回転させる必要 がある。メカニカルチョッパーは夕ーボ分子ポ ンプの駆動部を利用することにより，4800〜 $20000 \mathrm{rpm}$ の範囲で $10^{-7}$ Torr台の真空度とする ことができた。本実験で用いたメカニカル チョッパーは，申 $400 \mathrm{~mm}$ のAl円盤に幅 $1 \mathrm{~mm}$ の スリットが4つある構造となっている。このた めフォトダイオードからの信号は，400１300 $\mathrm{Hz}$ とレーザーの最高繰り返し可能周波数に比 ベ高いため，パルスカウント回路を設けること により同期可能とした。

アブレーション粒子の運動エネルギーの選択 範囲は, フォトカプラからの信号を基準として レーザーを照射するディレイ時間をコントロー ルすることにより行った。
メカニカルチョッパー上のスリットを通過し たアブレーション粒子の持つ速度の測定は，四 重極子質量分析計をチョッパー上におきター ゲットから分析計までの飛行時間(Flight Time) を計測することにより行い, 飛行粒子の持つ運 動エネルギーを求めた。

実験は, $\mathrm{KrF}$ エシマレーザー $(\lambda=248 \mathrm{~nm}$ $14 \mathrm{nsec})$ を Au及びPt夕ーゲットに照射して行っ た。スリットを通過する粒子の持つ速度範囲は, レーザー照射遅延時間, メカニカルチョッパー の回転数, ターゲット-チョッパー間距離によっ て変わるためこれら因子による選択特性変化の 計測を行った。その後成膜を行い速度範囲選択 の効果の確認をした。

\section{3. 結果及び考察}

Fig. 2にレーザーアブレーションにより形成 された $\mathrm{Au}$ イオンの速度分布を示す。アブレー ションされた粒子の速度は $10^{5} \mathrm{~cm} / \mathrm{sec}$ 台であ り, これらの粒子が持つ運動エネルギーは数 $\mathrm{eV}$ 数十 $\mathrm{eV}$ と比較的高いエネルギーを持って いる。

Fig. 3にレーザー照射の遅延(ディレイ)時間 の設定を変えたときに，メカニカルチョッパー のスリットを通過する粒子の持つエネルギー範 囲を測定した結果を示す。

ここで言うディレイ時間とは，フォトカプラ によりターゲット直上にスリットがあることを 検出後, 次のスリットにアブレーション粒子を

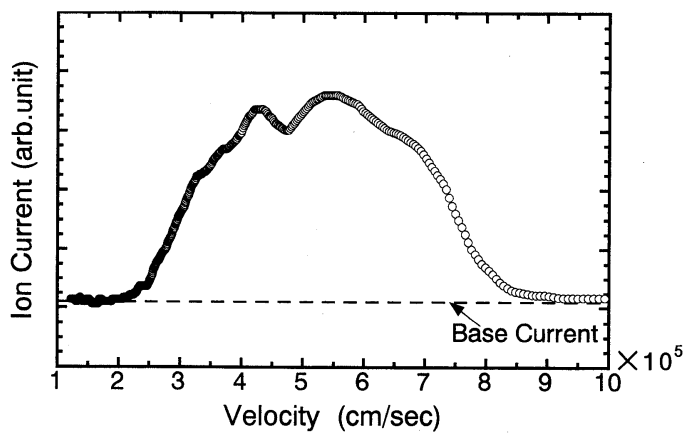

Fig. 2 Velocity distribution of $\mathrm{Au}$ ions formed by $\mathrm{KrF}$ laser irradiation. 


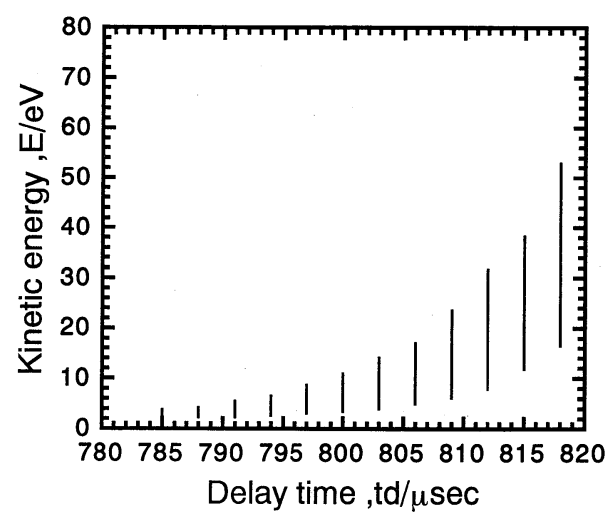

(a)

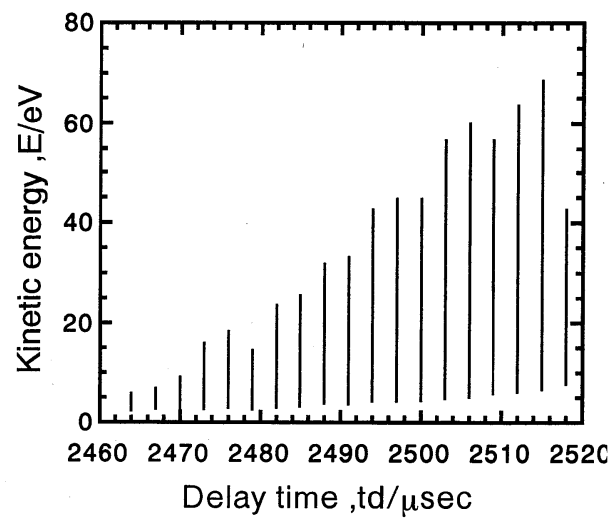

(b)

Fig. 3 Experimental energy region of the particle which is passed through a slit as a function of delay time for various mechanical-chopper revolution speeds. (a) $18000 \mathrm{rpm}$; (b) 6000 rpm.

通過させるためにとるレーザー照射の遅延時間 のことである。ディレイ時間が小さい場合には レーザー照射からスリット通過まで時間がある ため高速粒子はスリットの通過前にチョッパー に到達しスリットを通り抜けることができな い。その結果低速粒子を選択的にチョッパーを 通過させることができる。逆にディレイ時間を 大きくした場合，レーザー照射からスリット通 過までの時間が短いため高速粒子のみ選択的に チョッパーを通過させることができる。

図中に見られるように，本方式では低エネル
ギー粒子を選択しようとした場合その選択範囲 は狭いが，高エネルギー粒子を選択した場合は 選択範囲は広くなるといった選択特性を持って いる。これは，スリットの開放時間一定で，夕 イミングのみ変化させているためであり, 高速 粒子ほど時間的広がりが小さいことに起因して いる。

Fig. 3(a), (b)にチョッパーの回転数を変えた 場合の検出される粒子のエネルギー範囲を示 す。回転数を早くするほど選択される粒子のエ ネルギー範囲は小さくなりエネルギー選択性が 良くなることがわかる。これはチョッパーの回 転が遅い場合にはスリットの解放時間が長くな るためである。

また，スリットによる選択特性に影響を与え るもう1つの因子として, ターゲット-チョッ パー間距離がある。本装置では，この因子の選 択特性に及ぼす効果は基本的に，回転数による 効果と同じである。ターゲットまでの距離が遠 くなるほど，飛行粒子がチョッパーに到達する までの時間を要するため, 粒子の時間分布が広 くなるため, 選択特性は向上する。

この様に, レーザー照射遅延時間, メカニカ ルチョッパーの回転数, ターゲット-チョッパー 間距離を変えることにより，高速あるいは低速 粒子のみ，及びその両方をカットすることが可 能である。

レーザーアブレーションによる薄膜形成は数 多くの利点を持つが，問題点の1つとして数百 ÅーミクロンオーダーのDropletの発生による 表面モルフォロジーの低下が挙げられる。これ は夕ーゲット表面における不均一性の形成や, 過飽和粒子の表面における凝集によるものと考 えられている。

これらDropletの持つ速度は $10^{4} \mathrm{~cm} / \mathrm{sec}^{1-3)}$ 台と されている。Dropletは, 膜のモルフォロジー を低下させるだけでなく，膜特性自体に影響を 与えるためその抑制方法が各種提案されてい

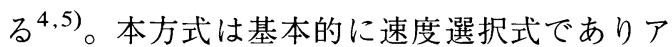
ブレーション粒子の中心帯域である $10^{5} \mathrm{~cm} / \mathrm{sec}$ オーダーの粒子をスリットに通過させようとし 
た場合，それより低速の粒子は基本的にカット され基板に到達することはできない。そのため 通常のレーザーアブレーション法で作製した $\mathrm{Au}$ 薄膜には $10^{5}$ 個 $/ \mathrm{cm}^{2}$ 程度のDropletが存在す るのに対し，本方式で作製した膜においては, Dropletの発生はほとんど見られず，Droplet抑 制にも効果があることが確認された。

\section{4. まとめ}

メカニカルチョッパーを用いた速度選択方式 により,レーザーアブレーションされた粒子の 成膜粒子の速度範囲選択が可能であることを確 認した。また本方式がDroplet発生抑止にも効 果があることが確認された。今後, 成膜粒子の 持つ運動エネルギー範囲を変えた場合の, 膜特 性に与える影響について明らかにしていく予定 である。

\section{謝辞}

本研究は, 通商産業省工業技術院の産業科学
技術研究開発制度に基づき実施されている「先 進機能創出加工技術の研究開発」の一環として, 新エネルギー・産業技術総合開発機構から先進 機能創出加工技術組合への委託事業によりまと めたものである。

\section{参 考 文 献}

1) O. Eryu, K. Murakami, K. Masuda, K. Shihoyama and T. Mochizuki: Jpn. J. Appl. Phys. 31 (1992) L86.

2) H. Dupendant, J. P. Gavigan, D. Givord, A. Lienard, J. P. Rebouillat and Y. Souche: Appl. Surf. Sci. 43 (1989) 369.

3) D. Lubben, S. A. Barnett, K. Suzuki, S. Gorbatkin and J. E. Greene: J. Vac. Sci. Technol. B3 (1985) 4, 968.

4) 小林正樹, 辻原清人, 英貢, 古野志健男, 井口 哲：レーザー学会第13回年次大会予稿集, (1993年)p. 157.

5) T. Venkatesan, X. D. Wu, R. Muenchausen and A. Pique: MRS Bulletin, 17 (1992) 2, 54. 